Nevșehir Bilim ve Teknoloji Dergisi Cilt 5(2) 167-184 2016

DOI: 10.17100/nevbiltek.284740

URL: http://dx.doi.org/10.17100/nevbiltek.284740

\title{
Bankacılık Sektöründe Müşteri Değerlendirme Kriterleri Seçiminde Örnek Bir Karar Verme Süreci
}

\author{
Feyza GÜRBÜZ*
}

Erciyes Üniversitesi, Mühendislik Fakültesi, Endüstri Mühendisliği Bölümü, 38039, KAYSERI

Öz

Günümüzdeki hızlı değişen ve zorlaşan çalışma ve hayat koşulları, insanları ve kurumları "iyi" ve "başarılı" karar vermeye zorlamaktadır. Böyle bir çevrede ayakta kalabilmek ve rekabet avantajıyla birlikte bunu sürdürmek de önem kazanmaktadır. Böylece sağlıklı karar verme bir gereklilik olmaktadır. Stratejik seçimler yapılırken, etrafta olabilecek gelişmeleri ve firmalarını etkileyecek faktörleri takip etmek zorunludur. Değişen müşteri beklentileri ve talepleri, teknolojik süreçler, demografik değişiklikler bu faktörlerdendir. Söz konusu bir finans kurumu ise müşterilerinin olası davranışları kurum faaliyetlerini ve geleceğini etkileyebilmektedir. Bu çalışmada, Türkiye'de faaliyet gösteren bir finans kurumunun kendileri için önemli müşterileri seçerek, onlara yönelik stratejiler belirlemesi için bir karar verme süreci tanımlanmıştır.

Anahtar Kelimeler: Çok Kriterli Karar Verme, Swot Analizi, Topsis, Banka Müşteri Seçimi.

\section{A Decision Making Process For Evaluation the Customers of Finance Company}

\section{Abstract}

Nowadays, people must make good and succesful decisions in difficult life and working conditions. To survive in such an environment with a competitive advantage becomes more of an issue. Thus, healthy decision-making is a necessity in this environment. When making strategic choices, we must track developments and factors that may be around and affect the firms. These factors may be, customer expectations and demands, technological processes, demographic changes. If the finance firm is discussed, the possible behaviors of customers can affect the activities of the institution and the future of the firm. In this study, we have described a decision making process of a financial institution that operates in Turkey via selection of the important customers.

Keywords: Multi-Criteria Decision Making, Swot Analysis, Topsis, Bank Customer Selection.

"e-mail: feyza@erciyes.edu.tr 


\section{Gürbüz F.}

\section{Giriş}

Geleneksel olarak bir karara ulaşılırken, karar süreci ile ilgili veriler toplanır ve sezgisel olarak analiz edilerek sonuca varılır. Ancak artık birçok durumda başarılı kararlar verebilmek için alternatif davranış yolları bilimsel karar verme tekniklerinin desteği ile değerlendirilmektedir [1].

Gerçek hayatta karşılaşılan karar problemleri, karar süreçlerine birden fazla faktörün dahil olması, karar durumlarındaki belirsizlikler, kararın sonuçlarının bir çok kişiyi ilgilendirmesi ve hayati önem taşıyor olması gibi nedenlerle karmaşık bir yapıdadırlar. Karar vericiye bu tür problemlerin üstesinden gelmesinde yardımcı olan bilimsel teoriler ve analitik yöntemler geliştirilmiştir.

Yönetim konusunda son y1llarda giderek artan ve oldukça ilgi gören Çok Kriterli Karar Verme, bir karar durumu ile ilgili olarak birbiri ile çatışan birden fazla kriteri karşılayan olası en uygun çözüme ulaşmaya çalışan yaklaşım ve yöntemleri bünyesinde barındırmaktadır.

İşletmelerin aldıkları kararlarda oldukça büyük öneme sahip müşteriler, işletmeler için en değerli varlıklar olduğu gibi işletmelerin devamlılığı sağlayabilmek için kilit noktasıdır. Müşterisi olmayan firma için satış ve dolayısıyla kar söz konusu olamaz. Bu yüzden müşteri ile iyi ilişkiler sürdürülmesi, işletmenin hayati sorunlarındandır. Günümüzde ise müşterilerin değişen, gelişen beklenti ve isteklerine cevap veren işletmelerin varlıklarını sürdürebildikleri, karlılıklarını artırdıkları görülmektedir. Müşterilerin isteklerine göre hizmet sunan işletmelerin aksine bunları uygulamayan işletmelerin karlılıklarını azalttıkları, sonrasında yok oldukları görülmektedir. Müşterisi olmayan firma için satış ve dolayısıyla kar söz konusu olamaz. Bu yüzden müşteri ile iyi ilişkiler sürdürülmesi, işletmenin hayati sorunlarındandır $[2,3]$.

Müşterilerini yakından tanıyan firmaların, onların memnuniyetlerini sağlaması veya memnuniyet düzeylerini artırması daha kolay olacaktır. Tüm sektörler arasında hizmet sektörünün giderek önem kazanması ve ülke ekonomilerinde büyük pay sahibi olması bu sektörün ekonomi içerisindeki ağırlığının bir gelişmişlik ölçütü olarak değerlendirilmesini sağlamaktadır. Diğer sektörlerin faaliyetlerinin büyük bir kısmının etkinleştirilmesinde ve kolaylaştırılmasında hizmet sektöründe yer alan bankalar önemli fonksiyonlar üstlenmektedirler [4].

Değişken çevre ve artan rekabet koşulları altında rakipleriyle sürekli bir yarış içinde olan bankalar, hizmetlerini sürekli olarak geliştirmekte ve daha gelişmiş bir teknolojik altyapı ve hizmet sunmaya çalışmaktadır. $\mathrm{Bu}$ çalışmalarla müşteri sayısını ve karlılığını sürdürülebilir biçimde arttırmayı amaçlamaktadır [5].

Bankaların müşterilerini etkileme çabaları ve müşterilerin bankayla ilgili geçmiş deneyimleri potansiyel müşterilerde bankalarla ilgili belirli algılar oluşturmaktadır. Bu algılar çoğunlukla, bireylerin bankacılık hizmetlerini kullanıp kullanmama kararı veya banka tercihleri açısından önem kazanmaktadır [5].

Müşterilere hizmet sağlamada, işletmelerin yaptıkları/sundukları yenilikler/kolaylıklar sadece (ödeme kolaylığı, kredi, taksit, sigorta ve internet üzerinden satış imkanı sunma gibi hususlar) yeterli olmamaktadır. Ayrıca bankaların da bu yenilikleri/kolaylıkları destekleyici politikalar izlemeleri gerekir. $\mathrm{Bu}$ açıdan bakıldığında bankalar, hem ticarî hem de bireysel müşterilerine verdikleri hizmeti sürekli geliştirmelidirler [4]. 
Bankacılığın en önemli sermayesi insanların bankacılık kurumuna ve çalışanına güvenidir. Bankalar mevcut müşterileri elde tutmak için farklı, yeni müşteriler kazanmak için farklı yöntemler denemektedir. Ayrıca bankalar mevcut müşterilerin kullandıkları ürün sayısı arttırmaya çalışmakta, mevcut müşterilerin sunulan diğer hizmetleri de kullanması için çaba göstermektedir. Bu çerçevede mevcut müşterilerin düzenli şekilde ziyaret etmek, ihtiyaçlarını belirlemek, kendilerine her yeni ürün ve hizmet hakkında bilgilendirmek bankaların müşteri ilişkilerini yönetmek açısından kullandığı temel ilkelerdir.

Çalışma kapsamında bir bankanın kendisi ile çalışmakta olan müşterilerinin değerlendirilmesinde, Swot analizi ve Çok Kriterli Karar Verme yöntemlerinden Topsis yönteminin birlikte kullanılması esas alınmıştır. Çalışmanın ilk aşamasında ilgili banka çalışanları (bölge müdürü, müdür, müdür yardımcısı ve birim şefleri) ile bir grup görüşmesi yapılarak önemli müşteriler belirlenmiştir. Belirlenen müşteriler bireysel müşteriler olmayıp yüksek miktarlarda nakit akışı sağlayan firmalardan oluşturulmuştur. Görüşmenin amacı Swot analizi ile belirlenen kriterler açısından hangi müşterinin kurum için daha önemli olduklarının belirlenmesidir.

Günümüzde TOPSIS yönteminin Çok Kriterli Karar Verme Yöntemleri arasında en yaygın kullanılan yöntemlerden olmasından dolayı birçok alanda yapılan çalışmaya konu olmuştur. Bankalar da bu alanlardan birisidir. Literatürde yer alan çalışmalardan bazıları şunlardır:

Demireli, Türkiye'de faaliyet gösteren kamu sermayeli bankaların performanslarının TOPSIS yöntemiyle belirlemiştir [6]. Cheng-Ru Wu, bankaların sermaye yönetiminde örgütsel performanslarının değerlendirilmesinde [7], Hui Yin Tasai [8], sigorta işletmelerinin performanslarının değerlendirilmesinde, Manabendra [9], bankacılık sektörünün hizmet kalitesinin değerlendirilmesinde, Tolga [10], yatırımların finansal açıdan değerlendirilmesinde, Seçme [11], bankacılık sektöründe finansal performansın değerlendirilmesinde, İç [12], bankaların üretim firmalarının kredibilitesinin değerlendirmesinde, Demireli [6], kamu bankalarının performanslarının değerlendirilmesinde Topsis yöntemini kullanmışlardır.

Topsis yöntemi, Demireli ve Saldanlı'da finansal performans göstergelerinin analizinde kullanılmıştır [6, 13].

Çok kriterli karar verme yöntemlerinden topsis dişında bankalara uygulanan farklı yöntemler de mevcuttur. Bunlardan bazıları şu şekildedir.

Güneysu vd., yaptıkları çalı̧̧mada ilk olarak Analitik Hiyerarşi Süreci (AHS) yöntemi, kriterlerin (finansal oranlar) ağırlıklarının belirlenmesi amacıyla kullanılmış ve bankaların performanslarının değerlendirilmesinde ana kriterlerden kârlılık oranlarının, alt kriterlerden ise sermaye yeterliliği standart oranının en fazla öneme sahip olduğu ortaya çıkmıştır. Gri İlişkisel Analiz (GİA) yöntemi ise ikinci aşamada bankaları finansal performanslarına göre sıralamak amacıyla kullanılmıştır [14].

Soba çalışmasında, banka yeri seçiminin kolaylaştırılması için Çok Kriterli Karar Verme metotlarından Analitik Hiyerarşi Süreci ve Electre Metotları kullanılarak karar vericilerin sağlıklı bir seçim yapabilmesi amaçlanmıştır [15].

Dinçer ve Görener Türkiye’deki kamu, özel ve yabancı sermayeli banka gruplarının performans ölçümüne ilişkin değerlendirme kriterlerinin ağırlıklarını, analitik hiyerarşi süreci (AHP) yardımıyla 
hesaplamış, sonrasında VIKOR ve TOPSIS yöntemlerini kullanarak ilgili birimlerin performans değerlendirmelerini yapmışlardır [16].

Bağcı ve Rençber, çalışmalarında kamu bankaları ile özel bankalar arasında kârlılık performansları karşılaştırması yapmışlardır. Bu ölçüm Promethee yöntemi ile yapılmıştır. Bu analizler için 3 kamu bankası ve halka açık 10 özel banka kullanılmıştır. Analiz 2006-2012 yılları arasını kapsamaktadır. Uygulamada kullanılacak verilere tbb.org.tr adresindeki bilanço ve gelir tablolarından ulaşılmıştır [17].

Yapılan literatür araştırmasında da görüldüğü gibi, bankaların müşterilerine yönelik strateji belirlemeleri üzerine çok kriterli karar verme teknikleri ile yapılmış çalışmalara rastlanılmamıştır.

\section{Materyal ve Metot}

\subsection{Swot Analizi}

Swot analizi, herhangi bir kuruluşun, örgütün, kamu kurumunun ya da özel sektör firmasının içsel durumunu ve onu çevreleyen dışsal faktörleri tahlil etmek için kullanılan yöntemlerden biridir. Bir anlamda, mevcut durumun, tüm yönleriyle, iç ve diş dinamiklerin de göz önünde bulundurulmasıyla, fotoğrafının çekilmesidir.

Kökleri 1950lere uzanmakla birlikte, akademik biçimini alması, 1970lerde Stanford'da olmuştur. Kullanım alanı, şirket analizlerinden bireysel kariyer planlamaya kadar geniş bir yelpazedir.

Swot analizi, üzerinde çalışılan konunun güçlü ve zayıf yönlerini belirlemekle birlikte dış çevre kaynaklı fırsat ve tehditleri saptamakta kullanılan bir tekniktir. Swot analizinin amacı; iç ve dış etkenleri dikkate alarak, mevcutta olan güçlü yönler ve firsatlardan en üst düzeyde yararlanarak, tehditlerin ve zayıf yanların etkisini en aza indirerek plan ve stratejiler geliştirmektir.

Organizasyonlarda SWOT Analizi yapılmasının başlıca iki yararı bulunmaktadır. İlk olarak, SWOT Analizi yapılarak organizasyonun mevcut durumu tespit edilir. Bu çerçevede güçlü ve zayıf yönler ile organizasyonun karşı karşıya bulunduğu firsatlar ve tehdit unsurları ortaya konulmaya çalışılır. Bu anlamda SWOT bir "Mevcut Durum Analizi"dir. SWOT aynı zamanda organizasyonun gelecekteki durumunun ne olacağı tespit ve tahmin etmeye yarayan bir analiz tekniğidir. Bu ikinci anlamda SWOT bir “Gelecek Durum Analizi”dir. Bu açıklamalar çerçevesinde SWOT Analizini yakını ve uzağı görmemizi sağlayan bir gözlük olarak algılayabiliriz [18].

İşletmeler kendi çevrelerinde yaşanmakta olan gelişmelerden haberdar olmak zorundadır ve sürekli bir şekilde çevresel tarama ve izleme yapmaya mecburdur. Bu tarama ve izleme faaliyeti bir nevi erken uyarı sistemi görevi görmektedir. SWOT Analizi tamamlandığında işletme kendisi ve çevresi hakkında olumlu ve olumsuz yönler açısından bilgilenmiş durumdadır. İşletmenin üstün ve zayıf yönleri 1şı̆̆ında işletme yeni firsatlar yakalamak amacıyla kendine yeni hedefler belirleyecek ve yeni firsat pencerelerini kullanmaya çalışacaktır [19].

$\mathrm{Bu}$ çalışmada bir finans kurumunun geleceğine yön vermesinde etkili olduğunu düşündüğü müşteri gruplarının Swot analizi yapılmıştır. Böylece belirlenen 10 müşteri grubunun her biri için güçlü yönleri ve zayıf yönleri ile firsat ve tehditleri grup üyelerince belirlenmiştir. 


\subsection{Topsis Yöntemi}

TOPSIS (Technique for Order Preference by Similarity to Ideal Solution) Yoon ve Hwang tarafından 1980 yılında geliştirilmiştir. Karar noktalarının ideal çözüme yakınlığı ana prensibine dayanır. TOPSIS yöntemi 6 adımdan oluşan bir çözüm sürecini içerir. Aşağıda TOPSIS yönteminin adımları tanımlanmıştır [20, 21].

Adım 1 : Karar Matrisinin (A) Oluşturulması

Karar matrisinin satırlarında üstünlükleri sıralanmak istenen karar noktaları, sütunlarında ise karar vermede kullanılacak değerlendirme faktörleri yer alır. A matrisi karar verici tarafından oluşturulan başlangıç matrisidir. Karar matrisi aşağıdaki gibi gösterilir:

$$
A_{i j}=\left[\begin{array}{cccc}
a_{11} & a_{12} & \ldots & a_{1 n} \\
a_{21} & a_{22} & \ldots & a_{2 n} \\
\cdot & & & \cdot \\
\cdot & & & \cdot \\
\cdot & & & \cdot \\
a_{m 1} & a_{m 2} & \ldots & a_{m n}
\end{array}\right]
$$

Aij matrisinde m karar noktası sayısını, $\mathrm{n}$ değerlendirme faktörü sayısını verir.

Adım 2 : Standart Karar Matrisinin (R) Oluşturulması

Standart Karar Matrisi, A matrisinin elemanlarından yararlanarak ve aşağıdaki formül kullanılarak hesaplanır.

$$
r_{i j}=\frac{a_{i j}}{\sqrt{\sum_{k=1}^{m} a_{k j}^{2}}}
$$

R matrisi aşağıdaki gibi elde edilir:

$$
R_{i j}=\left[\begin{array}{cccc}
r_{11} & r_{12} & \ldots & r_{1 n} \\
r_{21} & r_{22} & \ldots & r_{2 n} \\
\cdot & & & \cdot \\
\cdot & & & \cdot \\
\cdot & & & \cdot \\
r_{m 1} & r_{m 2} & \ldots & r_{m n}
\end{array}\right]
$$

Adım 3 : Ağırlıklı Standart Karar Matrisinin (V) Oluşturulması

Öncelikle değerlendirme faktörlerine ilişkin ağırlık değerleri (Wi ) belirlenir:

$$
\sum_{i=1}^{n} w_{i}=1
$$

Daha sonra $\mathrm{R}$ matrisinin her bir sütunundaki elemanlar ilgili Wi değeri ile çarpılarak $\mathrm{V}$ matrisi oluşturulur. V matrisi aşağıda gösterilmiştir: 


$$
V_{i j}=\left[\begin{array}{cccc}
w_{1} r_{11} & w_{2} r_{12} & \ldots & w_{n} r_{1 n} \\
w_{1} r_{21} & w_{2} r_{22} & \ldots & w_{n} r_{2 n} \\
\cdot & & & \cdot \\
\cdot & & & \cdot \\
\cdot & & & \cdot \\
w_{1} r_{m 1} & w_{2} r_{m 2} & \ldots & w_{n} r_{m n}
\end{array}\right]
$$

Adım 4 : İdeal (A*) ve Negatif İdeal (A- ) Çözümlerin Oluşturulması

TOPSIS yöntemi, her bir değerlendirme faktörünün monoton artan veya azalan bir eğilime sahip olduğunu varsaymaktadır.

İdeal çözüm setinin oluşturulabilmesi için $\mathrm{V}$ matrisindeki ağırlıklandırılmış değerlendirme faktörlerinin yani sütun değerlerinin en büyükleri (ilgili değerlendirme faktörü minimizasyon yönlü ise en küçügü) seçilir. İdeal çözüm setinin bulunması aşağıdaki formülde gösterilmiştir.

$$
A^{*}=\left\{\left(\max _{i} v_{i j} \mid j \in J\right),\left(\min _{i} v_{i j} \mid j \in J^{\prime}\right\}\right.
$$

(2.6) formülünden hesaplanacak set şeklinde gösterilebilir.

Negatif ideal çözüm seti ise, V matrisindeki ağırlıklandırılmış değerlendirme faktörlerinin yani sütun değerlerinin en küçükleri (ilgili değerlendirme faktörü maksimizasyon yönlü ise en büyügü̈) seçilerek oluşturulur. Negatif ideal çözüm setinin bulunması aşağıdaki formülde gösterilmiştir.

$$
A^{-}=\left\{\left(\min _{i} v_{i j} \mid j \in J\right),\left(\max _{i} v_{i j} \mid j \in J^{\prime}\right\}\right.
$$

(2.7) formülünden hesaplanacak set $A^{*}=\left\{v_{1}^{*}, v_{2}^{*}, \ldots, v_{n}^{*}\right\}$ şeklinde gösterilebilir.

Her iki formülde de $\mathrm{J}$ fayda (maksimizasyon), $\mathrm{J}$ ' ise kayp (minimizasyon) değerini göstermektedir.

Gerek ideal gerekse negatif ideal çözüm seti, değerlendirme faktörü sayısı yani m elemandan oluşmaktadır.

\section{Adım 5 : Ayırım Ölçülerinin Hesaplanması}

TOPSIS yönteminde her bir karar noktasına ilişkin değerlendirme faktör değerinin İdeal ve negatif ideal çözüm setinden sapmalarının bulunabilmesi için Euclidian Uzaklık Yaklaşımından yararlanılmaktadır. Buradan elde edilen karar noktalarına ilişkin sapma değerleri ise İdeal Ayırım ( $\mathrm{S}_{\mathrm{i}}^{*}$ ) ve Negatif İdeal Ayırım ( $\mathrm{S}_{\mathrm{i}}^{-}$) Ölçüsü olarak adlandırılmaktadır. İdeal ayırım

$\left(\mathrm{S}_{\mathrm{i}}{ }^{*}\right)$ ölçüsünün hesaplanması $(2.8)$ formülünde, negatif ideal ayırım $\left(\mathrm{S}_{\mathrm{i}}{ }^{-}\right)$ölçüsünün hesaplanması ise (2.9) formülünde gösterilmiştir.

$$
\begin{aligned}
& S_{i}^{*}=\sqrt{\sum_{j=1}^{n}\left(v_{i j}-v_{j}^{*}\right)^{2}} \\
& S_{i}^{-}=\sqrt{\sum_{j=1}^{n}\left(v_{i j}-v_{j}^{-}\right)^{2}}
\end{aligned}
$$

Burada hesaplanacak $\left(\mathrm{S}_{\mathrm{i}}^{*}\right)$ ve $\left(\mathrm{S}_{\mathrm{i}}^{-}\right)$sayısı doğal olarak karar noktası sayısı kadar olacaktır. 


\section{Adım 6 : İdeal Çözüme Göreli Yakınlı̆̆ın Hesaplanması}

Her bir karar noktasının ideal çözüme göreli yakınlığının $\left(C_{i}^{*}\right)$ hesaplanmasında ideal ve negatif ideal ayırım ölçülerinden yararlanılır. Burada kullanılan ölçüt, negatif ideal ayırım ölçüsünün toplam ayırım ölçüsü içindeki payıdır. İdeal çözüme göreli yakınlık değerinin hesaplanması aşağıdaki formülde gösterilmiştir.

$$
C_{i}^{*}=\frac{S_{i}^{-}}{S_{i}^{-}+S_{i}^{*}}
$$

Burada $\left(C_{i}^{*}\right)$ değeri $0 \leq C_{i}^{*} \leq 1$ aralığında değer alır ve $C_{i}^{*}=1$ ilgili karar noktasının ideal çözüme, ilgili karar noktasının negatif ideal çözüme mutlak yakınlığını gösterir.

\section{Bulgular}

Çalışmanın ilk bölümünde banka yöneticilerinden oluşan 7 kişilik bir grup ile yapılan görüşmeler sonucunda banka için oldukça önemli olabilecek müşteri grupları incelenmiş ve bunlardan ilk 10 tanesi çalışma kapsamına alınmıştır. Daha sonra belirlenmiş olan 10 müşterinin her birisi için Swot analizleri yapılmıştır. Her bir müşteri için yapılan Swot analizleri grup tarafından tartışılıp onaylanarak son durumları Tablo 1'de verildiği gibi belirlenmiştir.

Tablo 1. Müșteriler için belirlenmiș Swot faktörleri

\begin{tabular}{|c|c|c|}
\hline SWOT & Müşteri 1 & Müşteri 2 \\
\hline \multicolumn{3}{|l|}{ FAKTÖRLERİ } \\
\hline $\begin{array}{l}\text { GÜÇLÜ } \\
\text { YÖNLER }\end{array}$ & $\begin{array}{l}\text { Müşterinin birden fazla şubesi olması nedeni ile pos } \\
\text { cirosuna olumlu katkı sağlar. Şubeye cari mevduat } \\
\text { katkısı sağlar. }\end{array}$ & $\begin{array}{l}\text { Şubenin en yüksek tutarlı yatırım müşterisi. Sıklıkla } \\
\text { nakit kredi kullanır. }\end{array}$ \\
\hline $\begin{array}{l}\text { ZAYIF } \\
\text { YÖNLER }\end{array}$ & $\begin{array}{l}\text { Kredi kullanmaz. Sektör kanunlardan olumsuz } \\
\text { etkilenebilir. Ciro düşebilir. }\end{array}$ & $\begin{array}{l}\text { Mevduat katkısı sağlamaz. Müşteri risk grubu } \\
\text { yüksektir. }\end{array}$ \\
\hline FIRSATLAR & $\begin{array}{l}\text { Her türlü ürün çapraz satışı yapılabilir; nakit } \\
\text { ihtiyaçlarında pos bloke çözümü yapan müşteriden } \\
\text { yüksek komisyon elde edilebilir. }\end{array}$ & $\begin{array}{l}\text { Nakit kredi ihtiyacı nedeni ile sigorta komisyon vb. } \\
\text { çapraz ürün satışı yapılabilir. Fiyat hassasiyeti } \\
\text { yoktur; yüksek fiyattan kredi kullandırılabilir }\end{array}$ \\
\hline \multirow[t]{2}{*}{ TEHDITLER } & $\begin{array}{l}\text { Amatör yönetim nedeni ile şahsi ilişkiye dayalı } \\
\text { çalışma; en ufak nedenden müşteri kaybedilebilir. } \\
\text { Çok itina gösterilmeli. }\end{array}$ & $\begin{array}{l}\text { Sektör itibarı ile risk grubunun yüksek olması nedeni } \\
\text { ile kredinin geri ödenmeme; takip riski mevcuttur- } \\
\text { kredinin takibe düşmesine şube karşılık giderlerini } \\
\text { artırır }\end{array}$ \\
\hline & Müşteri 3 & Müşteri 4 \\
\hline $\begin{array}{l}\text { GÜÇLÜ } \\
\text { YÖNLER }\end{array}$ & $\begin{array}{l}\text { Yüksek tutarlı mevduat müşterisidir. Kurum } \\
\text { bağlılığı vardır. }\end{array}$ & $\begin{array}{l}\text { Yüksek tutarlı mevduat müşterisidir. Şube karlılığına } \\
\text { yüksek etki; yatırım rakamlarına olumlu katkı sağlar. }\end{array}$ \\
\hline $\begin{array}{l}\text { ZAYIF } \\
\text { YÖNLER }\end{array}$ & Kredi kullanmaz. Çapraz ürün kullanmaz. & Kredi kullanmaz. Kurum bağlılığı yoktur. \\
\hline FIRSATLAR & Şahsi ilişkileri sıcak tutup ilave mevduat alınabilir & $\begin{array}{l}\text { Bankamız oranları yüksek olursa ilave mevduat } \\
\text { alınabilir- çapraz ürün satışı yapılabilir. }\end{array}$ \\
\hline TEHDITLER & $\begin{array}{l}\text { Mevduat oran hassasiyeti vardır. Farklı bir } \\
\text { kurumdan daha yüksek oran teklif edilmesi halinde } \\
\text { mevduat çıkışı olabilir. Çıkışı şube hedeflerine } \\
\text { olumsuz yansır. Mevduat rakamının yüksek oluşu; } \\
\text { yerine yeni mevduat koyana kadar şubeyi çok } \\
\text { olumsuz etkiler. }\end{array}$ & $\begin{array}{l}\text { Mevduat oran hassasiyeti vardır. Farklı bir } \\
\text { kurumdan daha yüksek oran teklif edilmesi halinde } \\
\text { mevduat çıkışı olabilir. Çıkış şube hedeflerine } \\
\text { olumsuz yansır. Mevduat rakamının yüksek oluşu; } \\
\text { yerine yeni mevduat koyana kadar şubeyi çok } \\
\text { olumsuz etkiler. }\end{array}$ \\
\hline
\end{tabular}


Gürbüz F.

\begin{tabular}{|c|c|}
\hline & Müşteri 5 \\
\hline $\begin{array}{l}\text { GÜÇLÜ } \\
\text { YÖNLER }\end{array}$ & $\begin{array}{l}\text { Yüksek tutarlı mevduat müşterisi şube karlılığına } \\
\text { yüksek etki; şube hedef rakamlarına olumlu katkı } \\
\text { sağlar. }\end{array}$ \\
\hline $\begin{array}{l}\text { ZAYIF } \\
\text { YÖNLER }\end{array}$ & Kredi kullanmaz. Kurum bağlılığı yoktur. \\
\hline FIRSATLAR & $\begin{array}{l}\text { Çapraz ürün satışı yapılabilir. Çalıştığı sektör } \\
\text { itibarıyla ilişkilerin sıcak tutulması sureti ile yeni } \\
\text { müşteri kazanımında katkı sağlayabilir }\end{array}$ \\
\hline
\end{tabular}

TEHDITLER İlişki odaklı. Yaşanan herhangi bir olumsuzlukta küsüp tüm çalışmayı kesebilir. Çok iyi ilişki kurulmalı; özen gösterilmeli. Mevduat çıkışı şube hedeflerine olumsuz yansır; ikame mevduat bulmak için çok çaba sarf etmek gerekir.

\section{Müşteri 7}

GÜÇLÜ Yüksek tutarlı kredi müşterisidir; sektöründe yeterli

YÖNLER tecrübe donanıma sahiptir. Nakdi gayri nakdi kredi ve komisyon geliri sağlar.

ZAYIF Yeterli öz sermayeye sahip değildir. Bu borç

YÖNLER yükünü çevirememesi algısı oluşturmaktadır. Firma sürekli yakın takip gerektirmektedir.

FIRSATLAR Firmanın kredi taleplerinin karşılanması sonucu her türlü çapraz ürün satışı yapılabilir. Yüksek fiyattan kredi kullandırılabilir. Yüksek komisyon geliri elde edilebilir

TEHDITLER Son derece riskli müşteri çok yakın takip edilmelidir. Kredinin geri ödenemeyip takibe intikal etmesi söz konusu olabilir. Kredinin takibe düşmesi şubeyi sıkıntıya sokar.

\begin{tabular}{ll}
\hline & Müşteri 9 \\
GÜÇLÜ & Hem mevduat hem kredi müşterisidir. Kredi \\
YÖNLER & hacmine ve mevduat rakamlarına destek sağlar.
\end{tabular}

ZAYIF Teminat vermez. Firma ve ortakları hakkında detay YÖNLER bilgiye ulaşma imkânı yok

FIRSATLAR Çapraz ürün satışı yapılabilir. Fiyat hassasiyeti olmaması nedeni ile yüksek fiyattan kredi kullandırılabilir. Yüksek komisyon geliri elde edilir.

TEHDITLER Teminat vermemesi nedeni ile firmanın yaşayabileceği herhangi bir olumsuzlukta kredinin tahsil kabiliyeti yoktur. Kredinin takibe düşmesi şube karşılık giderlerini artırır.

\section{Müşteri 6}

En yüksek tutarlı gayri nakdi kredi müşterisi. Gayri nakdi kredi hedefleri konu müşteri ile gerçekleştirilebilir- şube yatırım rakamlarına olumlu katkısı vardır.

Kredi fiyatına son derece hassastır. Nakdi kredilerinden pay alınamaz. Hiçbir çapraz ürün satışı yapılamaz.

Konu firma ile çalışıyor olmak farklı firmalar ile çalışabilmek için bir referanstır. Firma referans gösterilerek başka müşteriler ile çalışma hacmi oluşturulabilir.

Firmanın piyasa bilinirliği çok güçlü; söz sahibi bir firma olması nedeni ile firma ile yaşanabilecek en ufak bir olumsuzluk bankanın piyasadaki moralitesini zedeler. Firma diğer müşterilere olumsuz referans vererek çalışma potansiyelini engelleyebilir.

\section{Müșteri 8}

Yüksek tutarlı mevduat müşterisidir. Şube mevduat rakamına olumlu katkı sağlar. Mevduat oran hassasiyeti yoktur. İlave maliyet gerektirmez.

Çapraz ürün satışı yapılamaz. Mevduat dışında hiçbir ürün kullanmaz.

İlişki yönetimi ile müşterinin farklı bankalardaki mevduatını bankamıza aktarma şansı vardır. Müşteri referansı ile yeni müşterileri portföye dâhil etme şansı vardir.

En ufak bir iletişim kazası tüm mevduatı çekmesine neden olur. Mevduatı çekmesi şube hedeflerine doldurulması güçtür. Müşteri referansı ile kazanılan diğer müşterileri de olumsuz etkiler

\section{Müșteri 10}

Yüksek tutarlı kredi müşterisidir. Devam eden yatırımlar nedeni ile sürekli finansman ihtiyacı doğar; nakit kredi kullanır. Şube yatırım hedeflerine olumlu katkı sağlar.

Mevduat desteği sağlamaz. Birçok banka ile aktif çalıştığı için çapraz ürün satışı yapılmaz. Nakit kredi ilişkisi dışında pazarlama yapma imkânı yok

Yeni müşteri referansı alınarak farklı firmalar ile iletişime geçilebilir. Firmanın müşterileri ile iletişim kurulup şube bireysel kredi hacmine katlı sağlanabilir. Riski birçok bankada dağılmıştır. Çapraz ürün satışı yapılamayan müşterinin cari hesap hareketinden pay alınamaması müşteri mali durumunun kontrolünü zorlaştırır. Yaşanması muhtemel olumsuzluklardan geç haber olunmasını ve diğer bankalardan önce aksiyon alınmasını engeller. $\mathrm{Bu}$ da firmanın kanuni takibe düşmesi durumunda; tahsil kabiliyetini zorlaştırır. Şubenin takip giderlerini ve karşılık giderlerini artırır. 


\subsection{Swot Analizinden Topsise Geçiş}

Yapılan Swot analizi sonuçları tekrar grup üyeleri ile görüşülerek Topsis yönteminde kullanılmak üzere müşterilerin değerlendirileceği kriterler belirlenmiştir. Görüşmeler sonucunda müşterilerin temel olarak 3 kritere göre değerlendirilmesinin uygun olduğu sonucuna varılmıştır. $\mathrm{Bu}$ kriterler;
1- Ciroya katk1s1
2- Güçlü olması
3- Bağımlılık'dır.

Ana kriterlerler belirlendikten sonra 3 kriterin de alt kriterleri yine grup üyelerinin öngördüğü şekilde belirlenmiştir. Belirlenen bu alt kriterler Tablo 2'de verilmiştir.

Tablo 2 . Müșteri değerlendirmede kullanılan alt kriterler

\begin{tabular}{llll} 
& \multicolumn{2}{c}{ Tablo 2. Müşterı değerlendirmede kullanılan alt kriterler } & \\
& Ciroya katkısı & Ana kriterler & Bağı̆lülılık olması \\
\hline \multirow{3}{*}{ Alt kriterler } & Yüksek tutarlı kredi kullanımı & Fazla şubesi olması & Müşteri Getirmesi \\
& Yüksek tutarlı mevduat & Öz sermaye çokluğu & Güvenilirlik \\
& Çapraz ürün satışı & Yatırım rakamlarına katkısı & - \\
\hline
\end{tabular}

Belirlenmiş olan bu 3 kriter ve alt kriterler esas alınarak ilk olarak kriterlerin öncelikleri Topsis yöntemi kullanılarak belirlenmiştir. Daha sonra alt kriterlerin öncelik sırası belirlenmiştir. En son olarak da her bir alt kritere göre hangi müşterinin daha önemli olduğu belirlenmiştir. Aşağıdaki bölümlerde sırasıyla bahsi geçen uygulamalar sırasıyla açıklanmıştır.

\subsection{Topsis Yöntemi ile Müşteri Seçimi Uygulaması}

Banka yöneticilerinin, kurum müşterilerinin bağımlılı̆̆ını sürekli kılmak ve onlara uygun olarak yapılacak promosyonlara karar vermeleri için kendileri için önemli olacak müşterilerini ve hangi alanda önemli olduklarını tespit etmesi önemlidir. Bu çalışmada bu konuda yöneticilere yardımcı olarak örnek bir karar verme süreci geliştirilerek anlatılmıştır.

Karar verme sürecinde, her bir müşteriye ait Swot analizi yardımıyla müşteri değerlendirilmesinde esas alınacak ana kriterler ve alt kriterler belirlenerek, müşteri seçiminde esas alınacak olan ana kriterlerin önceliklerinin belirlenmesi için topsis yöntemi kullanılmıştır. Çalışmanın başlangıcında kullanılacak bütün karşılaştırma matrisleri, karar verecek grup üyeleri tarafından oluşturulmuştur. Ana kriterlere ait karşılaştırmalar Tablo 3'de verilmiştir. Topsis yönteminin esaslarına göre ana kriterlerin önem sıralarının belirlenmesi adına sırasıyla yapılan işlemler sonucu elde edilen değerler örnek olması adına Tablo 4 ve Tablo 5'de gösterilmiştir. Yöntemde kullanılan ağırlıklar yine grup üyelerinin uygun gördüğü şekilde alınmıştır. Her bir karşılaştırma için belirlenen ağırlıklar işlemler sırasında aşağıdaki bölümlerde belirtilmiştir. (Diğer kriter ve alt kriterler için bütün adımların sonucunda elde edilen matrislerin tamamı çalışmada verilmemiştir. Sadece karşılaştırma matrisi ve sonuçlar verilmiştir.) 
Gürbüz F.

Tablo 3. Ana kriterler için karşılaștırma matrisi

\begin{tabular}{|c|c|c|c|}
\hline & Ciroya Katkısı & Güçlü Olması & Bağlılık \\
\hline Ciroya Katkısı & 1 & 3 & 6 \\
\hline Güçlü Olması & 0.333 & 1 & 4 \\
\hline Bağlılık & 0.166 & 0.25 & 1 \\
\hline
\end{tabular}

Tablo 4. Ana kriterler için normalize edilmiş karar matrisi

\begin{tabular}{llll}
\hline & Ciroya Katkısı & Güçlü Olması & Bağlıık \\
Ciroya Katkısı & 0.937 & 0.946 & 0.2966 \\
Güçlü Olması & 0.309 & 0.315 & 0.1976 \\
Bağıılık & 0.159 & 0.078 & 0.0493 \\
\hline
\end{tabular}

*Belirlenen Ağırlıklar: W1=0.33, W2=0.31, W3=036 şeklinde alınmıştır.

Tablo 5. Ana kriterler için ağırlıklı normalize edilmiş karar matrisi

\begin{tabular}{llll}
\hline & Ciroya Katkısı & Güçlü Olması & Bağlılık \\
Ciroya Katkısı & 0.03092 & 0.2933 & 0.2966 \\
Güçlü Olması & 0.01197 & 0.0977 & 0.1976 \\
Bağlılık & 0.05247 & 0.02442 & 0.0493 \\
\hline
\end{tabular}

İdeal çözüm için elde edilen parametre değerleri aşağıdaki gibidir.

$\mathrm{A}^{*}=(0.3092,0.2933,0.2966), \mathrm{A}^{-}=(0.0525,0.0242,0.0493)$

$\mathrm{S}_{1}{ }^{*}=0, \mathrm{~S}_{2}{ }^{*}=0.091, \mathrm{~S}_{3}{ }^{*}=0.1994$

$\mathrm{S}_{1^{-}}=0.1994, \mathrm{~S}_{2^{-}}=0.27736, \mathrm{~S}_{3^{-}}=0$

$\mathrm{C}_{1}^{*}=1, \mathrm{C}_{2}^{*}=0.7504, \mathrm{C}_{3}^{*}=0$

Elde edilen sonuçlara göre en önemli kriter $\mathrm{C}_{1}{ }^{*}=1$ değeri ile Ciroya Katkısı, ikinci sırada $\mathrm{C}_{2}{ }^{*}=$ 0.7504 değeri ile Güçlü Olması ve son sırada $\mathrm{C}_{3}{ }^{*}=0$ değeri ile Bağllıı kriteridir.

Ana kriterlerin önem sırası belirlendikten sonra, her bir ana kriter için belirlenmiş alt kriterlerin önem dereceleri aşağıdaki gibi belirlenmiştir. Bağl1lık kriteri için karşılaştırma matrisi ve sonuçlar Tablo 6'da gösterilmiştir. Güçlü Olması ana kriterine ait alt kriterlerin karşılaştırma matrisi ve değerlendirme sonuçları Tablo 7'de son olarak da Ciroya Katkısı kriterinin alt kriterlerinin karşılaştırma matrisi ve değerlendirme sonuçları Tablo 8'de verilmiştir.

\section{a. Bağlılık Alt Kriterlerinin Değerlendirilmesi}

Tablo 6'da verildiği gibi, Bağlllık kriterinin alt kriterleri olan, Müşteri getirmesi ve Güvenilirlik kriterlerinin karşılaştırması grup üyeleri tarafindan yapılmıştır.

Tablo 6. Bağlılık alt kriterlerinin karşılaştırma matrisi

\begin{tabular}{lll}
\hline & Müşteri Getirmesi & Güvenilirlik \\
Müşteri Getirmesi & 1 & 0.1428 \\
Güvenilirlik & 7 & 1 \\
\hline
\end{tabular}

*Belirlenen ağırlıklar: W1 $=0.1358, \mathrm{~W} 2=0.8642$.

\section{İdeal Çözüm}

$$
\begin{aligned}
& \mathrm{A}^{*}=(0.0132,0.8556), \mathrm{A}^{-}=(0.0132,0.8556), \\
& \mathrm{S}_{1}{ }^{*}=0, \mathrm{~S}_{2}{ }^{*}=0, \mathrm{~S}_{3}{ }^{*}=0 \\
& \mathrm{~S}_{1}{ }^{-}=0, \mathrm{~S}_{2}{ }^{-}=0
\end{aligned}
$$


S değerlerimiz 0 (sıfır) olduğu için karşılaştırma yapılamaz. Alt kriterlerin birbirlerine üstünlüğü yoktur diyebiliriz.

\section{b. Güçlü Olması Alt Kriterlerinin Değerlendirilmesi}

Tablo 7'de verildiği gibi, Güçlü olması kriterinin alt kriterleri olan, Fazla şubesi olması, Öz sermaye çokluğu ve Yatırım rakamlarına katkısı, kriterlerinin karşılaştırması grup üyeleri tarafından yapılmıştır.

Tablo 7. Güçlü olması alt kriterlerinin karşılaştırma matrisi

\begin{tabular}{cccc}
\hline & Fazla Şubesi Olmasi & Öz Sermaye Çokluğu & Yatirim Rakamlarina Katkisi \\
Fazla Şubesi Olmasi & 1 & 1 & 0.1428 \\
Öz Sermaye Çokluğu & 1 & 1 & 0.166 \\
Yatirim Rakamlarina Katkisi & 7 & 6 & 1 \\
\hline *Belirlenen ağırlıklar: W1 $=0.33$, W2 $=0.34$, W3 $=0.33$. & &
\end{tabular}

\section{İdeal Çözüm}

$$
\begin{aligned}
& \mathrm{A}^{*}=(0.3234,0.3309,0.315), \mathrm{A}^{-}=(0.0462,0.0551,0.045) \\
& \mathrm{S}_{1}{ }^{*}=0.2258, \mathrm{~S}_{2}{ }^{*}=0.2215, \mathrm{~S}_{3}{ }^{*}=0 \\
& \mathrm{~S}_{1}{ }^{-}=0, \mathrm{~S}_{2}{ }^{-}=0, \mathrm{~S}_{3}{ }^{-}=0.2258 \\
& \mathrm{C}_{1}{ }^{*}=0, \mathrm{C}_{2}{ }^{*}=0, \mathrm{C}_{3}{ }^{*}=1 \\
& \mathrm{C}_{3}{ }^{*}=1 \text { değeri en büyük değer olduğu için Yatırım rakamlarına katkısı alt kriteri en önemli }
\end{aligned}
$$
kriterdir. Daha sonra ise Fazla şubesi olması ve Öz sermaye çokluğu gelmektedir.

\section{c. Ciroya Katkısı Alt Kriterlerinin Değerlendirilmesi}

Tablo 8'de gösterildiği üzere, Ciroya Katkısı kriterinin alt kriterleri olan, Yüksek tutarlı kredi kullanımı, Yüksek tutarlı mevduat ve Çapraz ürün satışı, kriterlerinin karşılaştırması grup üyeleri tarafindan yapılmıştır.

Tablo 8. Ciroya katkısı alt kriterlerinin karşılaştırma matrisi

\begin{tabular}{cccc}
\hline & Yüksek Tutarlı Kredi Kullanimi & Yüksek Tutarlı Mevduat & Çapraz Ürün Satı̧ıı \\
Yüksek Tutarı Kredi Kullanimi & 1 & 0.1428 & 3 \\
Yüksek Tutarı Mevduat & 7 & 1 & 9 \\
Çapraz Ürün Satışı & 0.333 & 0.111 & 1 \\
\hline
\end{tabular}

*Belirlenen ağırlıklar: $\mathrm{W} 1=0.31, \mathrm{~W} 2=0.33, \mathrm{~W} 3=0.36$.

\section{İdeal Çözüm}

$$
\begin{aligned}
& \mathrm{A}^{*}=(0.3065,0.325,0.339), \mathrm{A}^{-}=(0.014,0.036,0.037) \\
& \mathrm{S}_{1}{ }^{*}=0.4446, \mathrm{~S}_{2}{ }^{*}=0, \mathrm{~S}_{3}{ }^{*}=0.5101 \\
& \mathrm{~S}_{1}{ }^{-}=0, \mathrm{~S}^{-}=0.5101, \mathrm{~S}_{3}{ }^{-}=0 \\
& \mathrm{C}_{1}{ }^{*}=0.1565, \mathrm{C}_{2}{ }^{*}=1, \mathrm{C}_{3}{ }^{*}=\mathrm{O}
\end{aligned}
$$

Elde edilen $C^{*}$ değerlerine göre sıralayacak olursak, en önemli kriter Yüksek Tutarlı Mevduat, daha sonra Yüksek Tutarlı Kredi Kullanımı ve son olarak da Çapraz Ürün Satışıdır. 
Ana ve alt kriterlerin önceliklendirilmesinin ardından belirlenen 10 müşterinin her birisi alt kriterlere göre değerlendirilmiş ve öncelikleri belirlenmiştir. Bu alt kriterler yukarıda da bahsedildiği gibi Sırasıyla şöyledir:

1- Müşteri getirmesi,

2- Güvenilirlik,

3- Fazla şubesi olması,

4- Öz sermaye çokluğu,

5- Yatırım kararlarına katkısı,

6- Yüksek tutarlı mevduat kullanımı,

7- Çapraz ürün satışı,

8- Yüksek tutarlı kredi kullanımı.

Tablo 9-16 arasında belirlenen alt kriterlere göre aşağıda belirtilen adaylar (10 adet müşteri) tek tek grup üyeleri tarafından karşılaştırılmıştır.

Adaylar;

1=1. Müşteri, $2=2$. Müşteri, $3=3$. Müşteri, $4=4$. Müşteri, $5=5$. Müşteri

6=6. Müşteri, 7=7. Müşteri, $8=8$. Müşteri, $9=9$. Müşteri, $10=10$. Müşteri

d. Müşteri Getirmesi Alt Kriterine Göre Müşterilerin Değerlendirilmesi

\begin{tabular}{cccccccccccc}
\multicolumn{10}{c}{ Tablo 9. Müşteri getirmesi alt kriterine göre karş1laştırma matrisi } \\
\hline $\mathbf{1}$ & $\mathbf{1}$ & $\mathbf{2}$ & $\mathbf{3}$ & $\mathbf{4}$ & $\mathbf{5}$ & $\mathbf{6}$ & $\mathbf{7}$ & $\mathbf{8}$ & $\mathbf{9}$ & $\mathbf{1 0}$ \\
$\mathbf{2}$ & 1 & 1,25 & 2 & 3 & 0,33 & 2,5 & 2,25 & 0,33 & 2,25 & 0,9 \\
$\mathbf{3}$ & 0.8 & 1 & 1,5 & 2,25 & 0,25 & 1,75 & 1,2 & 0,25 & 1,2 & 0,5 \\
$\mathbf{4}$ & 0,5 & 0,66 & 1 & 1,5 & 0,16 & 1,16 & 0,83 & 0,16 & 0,83 & 0,4 \\
$\mathbf{5}$ & 3 & 4 & 0,44 & 0,66 & 1 & 0,11 & 0,77 & 0,55 & 0,11 & 0,55 & 0,2 \\
$\mathbf{6}$ & 0,4 & 0,57 & 0,85 & 1,28 & 0,14 & 1 & 0,71 & 0,14 & 0,71 & 0,25 \\
$\mathbf{7}$ & 0,44 & 0,83 & 1,2 & 1,8 & 0,2 & 1,4 & 1 & 0,2 & 1 & 0,4 \\
$\mathbf{8}$ & 3 & 4 & 6 & 9 & 1 & 7 & 5 & 1 & 5 & 2 \\
$\mathbf{9}$ & 0,44 & 0,83 & 1,2 & 1,8 & 0,2 & 1,4 & 1 & 0,2 & 1 & 0,4 \\
$\mathbf{1 0}$ & 1,11 & 2 & 2,5 & 5 & 0,5 & 4 & 2,5 & 0,5 & 2,5 & 1
\end{tabular}

*Belirlenen Ağırlıklar: W1 $=0.09, \mathrm{~W} 2=0.1, \mathrm{~W} 3=0.08, \mathrm{~W} 4=0.12, \mathrm{~W} 5=0.08, \mathrm{~W} 6=0.08, \mathrm{~W} 7=0.11, \mathrm{~W} 8=0.07$, $\mathrm{W} 9=0.13$, W10 $=0.14$.

İdeal Çözüm

\begin{tabular}{|ccccccccccccc}
\hline & 1 & 2 & 3 & 4 & 5 & 6 & 7 & 8 & 9 & 10 \\
MíN(A*) & 0,01 & 0,01 & 0,01 & 0,01 & 0,01 & 0,01 & 0,01 & 0,00 & 0,01 & 0,01 \\
MAK(A $\left.^{*}\right)$ & 0,06 & 0,06 & 0,05 & 0,07 & 0,05 & 0,05 & 0,07 & 0,04 & 0,08 & 0,09 \\
$\mathrm{~S}_{\mathrm{I}}^{*}$ & 0,130314 & 0,136553 & 0,11172 & 0,160726 & 0,109329 & 0,105981 & 0,145462 & 0,095663 & 0,17191 & 0,184296 \\
$\mathrm{~S}_{\mathrm{I}}^{-}$ & 0,076157 & 0,084385 & 0,067452 & 0,101229 & 0,067543 & 0,067624 & 0,092878 & 0,0591 & 0,109764 & 0,114745 \\
$\mathrm{C}_{\mathrm{I}}^{*}$ & 0,368851 & 0,381939 & 0,376465 & 0,386437 & 0,381875 & 0,389526 & 0,389685 & 0,381875 & 0,389685 & 0,38371 \\
\hline
\end{tabular}

İdeal çözüm değerlerine göre 7. müşteri ve 9. müşteri, müşteri getirmesi kriterine göre en önemli müşteri gruplarıdır. 
e. Güvenilirlik Alt Kriterine Göre Müşterilerin Değerlendirilmesi

Tablo 10. Güvenilirlik alt kriterine göre müşterilerin karşılaştırma matrisi

\begin{tabular}{cccccccccccc}
\hline & $\mathbf{1}$ & $\mathbf{2}$ & $\mathbf{3}$ & $\mathbf{4}$ & $\mathbf{5}$ & $\mathbf{6}$ & $\mathbf{7}$ & $\mathbf{8}$ & $\mathbf{9}$ & $\mathbf{1 0}$ \\
$\mathbf{1}$ & 1 & 0,14 & 0,85 & 0,28 & 1,4 & 1,4 & 0,9 & 1,28 & 1,75 & 0,38 \\
$\mathbf{2}$ & 7 & 1 & 6 & 2 & 5 & 5 & 8 & 9 & 4 & 3 \\
$\mathbf{3}$ & 1,66 & 0,16 & 1 & 0.26 & 0,71 & 0,71 & 1,33 & 1,5 & 0,6 & 0,5 \\
$\mathbf{4}$ & 3,5 & 0,5 & 3,75 & 1 & 2,5 & 2,5 & 4 & 4,5 & 2 & 1,5 \\
$\mathbf{5}$ & 0,71 & 0,2 & 1,4 & 0,4 & 1 & 1 & 0,75 & 1,8 & 0,8 & 0,63 \\
$\mathbf{6}$ & 0,71 & 0,2 & 1,4 & 0,4 & 1 & 1 & 1,6 & 1,75 & 1,25 & 1,55 \\
$\mathbf{7}$ & 1,11 & 0,13 & 0,75 & 0,25 & 1,33 & 0,63 & 1 & 1,13 & 0,5 & 0,38 \\
$\mathbf{8}$ & 0,77 & 0,11 & 0,66 & 0,22 & 0,55 & 0,57 & 0,88 & 1 & 0,44 & 0,33 \\
$\mathbf{9}$ & 0,44 & 0,25 & 1,66 & 0,5 & 1,25 & 0,8 & 2 & 2,25 & 1 & 0,8 \\
$\mathbf{1 0}$ & 2,33 & 0,33 & 2 & 0,66 & 1,58 & 0,6 & 2,66 & 3 & 1,25 & 1 \\
\hline
\end{tabular}

*Belirlenen Ağırlıklar: W1 $=0.08, \mathrm{~W} 2=0.09, \mathrm{~W} 3=0.11, \mathrm{~W} 4=0.07, \mathrm{~W} 5=0.14, \mathrm{~W} 6=0.08, \quad \mathrm{~W} 7=0.06, \mathrm{~W} 8=0.1$, W9 $=0.11$, W10 $=0.16$.

\section{İdeal Çözüm}

\begin{tabular}{|cccccccccccc}
\hline & 1 & 2 & 3 & 4 & 5 & 6 & 7 & 8 & 9 & 10 \\
MiN(A*) & 0,00 & 0,01 & 0,01 & 0,01 & 0,01 & 0,01 & 0,00 & 0,01 & 0,01 & 0,01 \\
MAK(A $\left.{ }^{*}\right)$ & 0,07 & 0,07 & 0,08 & 0,06 & 0,11 & 0,07 & 0,05 & 0,08 & 0,08 & 0,12 \\
$\mathrm{~S}^{\mathrm{I}^{*}}$ & 0,160108 & 0,168695 & 0,190246 & 0,132336 & 0,245474 & 0,157628 & 0,116042 & 0,187244 & 0,183771 & 0,268238 \\
$\mathrm{~S}^{\mathrm{i}-}$ & 0,071375 & 0,072845 & 0,089611 & 0,056775 & 0,112286 & 0,064699 & 0,050385 & 0,08077 & 0,088679 & 0,104145 \\
$\mathrm{C}^{\mathrm{i}}$ & 0,308338 & 0,301587 & 0,320203 & 0,30022 & 0,313859 & 0,29101 & 0,302745 & 0,301364 & 0,325488 & 0,279672 \\
\hline
\end{tabular}

İdeal çözüm değerlerine göre 9. müşteri, güvenilirlik kriterine göre en önemli müşteri grubudur.

\section{f. $\quad$ Fazla Şubesi Olması Alt Kriterine Göre Müşterilerin Değerlendirilmesi}

Tablo 11. Fazla şubesi olması alt kriteri için müşterilerin karşılaştırma matrisi

\begin{tabular}{cccccccccccc}
\multicolumn{10}{c}{ Tablo 11. Fazla şubesi olmas1 alt kriteri için müşterilerin karşılaştırma matrisi } \\
\hline $\mathbf{1}$ & $\mathbf{1}$ & $\mathbf{2}$ & $\mathbf{3}$ & $\mathbf{4}$ & $\mathbf{5}$ & $\mathbf{6}$ & $\mathbf{7}$ & $\mathbf{8}$ & $\mathbf{9}$ & $\mathbf{1 0}$ \\
$\mathbf{2}$ & 1 & 6 & 5 & 3 & 7 & 4 & 8 & 9 & 9 & 2 \\
$\mathbf{3}$ & 0,16 & 1 & 0,8 & 0,5 & 1,16 & 0,66 & 1,33 & 1,5 & 1,5 & 2 \\
$\mathbf{4}$ & 0,33 & 1,25 & 1 & 0,55 & 1,4 & 1,33 & 1,5 & 1,8 & 1,8 & 0,35 \\
$\mathbf{5}$ & 0,14 & 0,85 & 0,71 & 0,42 & 1 & 0,28 & 1,1 & 1,2 & 1,2 & 0,25 \\
$\mathbf{6}$ & 0,25 & 1,5 & 0,75 & 0,75 & 3,5 & 1 & 2 & 2,2 & 2,2 & 0,5 \\
$\mathbf{7}$ & 0,13 & 0,75 & 0,66 & 0,38 & 0,9 & 0,5 & 1 & 1,13 & 1,13 & 0,25 \\
$\mathbf{8}$ & 0,11 & 0,66 & 0,55 & 0,33 & 0,83 & 0,45 & 0,88 & 1 & 1 & 0,22 \\
$\mathbf{9}$ & 0,11 & 0,66 & 0,55 & 0,33 & 0,83 & 0,45 & 0,88 & 1 & 1 & 0,22 \\
$\mathbf{1 0}$ & 0,5 & 0,5 & 2,85 & 1,5 & 4 & 2 & 4 & 4,5 & 4,5 & 1 \\
\hline
\end{tabular}

*Belirlenen Ağırlıklar: W1 $=0.08, \mathrm{~W} 2=0.09, \mathrm{~W} 3=0.11, \mathrm{~W} 4=0.09, \mathrm{~W} 5=0.14, \mathrm{~W} 6=0.08, \mathrm{~W} 7=0.11, \mathrm{~W} 8=0.10$, $\mathrm{W} 9=0.12$, W10 $=0.08$.

\section{İdeal Çözüm}

\begin{tabular}{|c|c|c|c|c|c|c|c|c|c|c|}
\hline $\operatorname{MiN}\left(A^{-}\right)$ & 0,01 & 0,01 & 0,01 & 0,01 & 0,01 & 0,00 & 0,01 & 0,01 & 0,01 & 0,01 \\
\hline $\operatorname{MAK}\left(\mathrm{A}^{*}\right)$ & 0,06 & 0,08 & 0,09 & 0,07 & 0,10 & 0,06 & 0,09 & 0,08 & 0,10 & 0,05 \\
\hline $\mathrm{S}_{\dot{\mathrm{I}}}^{*}$ & 0,153361 & 0,196539 & 0,207857 & 0,172951 & 0,238076 & 0,149444 & 0,211443 & 0,191888 & 0,230266 & 0,113616 \\
\hline $\mathrm{S}_{\mathrm{I}}^{-}$ & 0,065076 & 0,076984 & 0,090248 & 0,073254 & 0,112874 & 0,070158 & 0,089541 & 0,081211 & 0,097454 & 0,072088 \\
\hline $\mathrm{C}_{\mathrm{I}}^{*}$ & 0,297915 & 0,281454 & 0,302739 & 0,297533 & 0,321624 & 0,319478 & 0,297494 & 0,297369 & 0,297369 & 0,388188 \\
\hline
\end{tabular}


Gürbüz F.

İdeal çözüm değerlerine göre 10. müşteri, fazla şubesi olması alt kriterine göre en önemli müşteri grubudur.

\section{g. Öz Sermaye Çokluğu Alt Kriterine Göre Müşterilerin Değerlendirilmesi}

Tablo 12. Öz sermaye çokluğu alt kriteri için müșterilerin karșılaștırma matrisi

\begin{tabular}{cccccccccccc}
\multicolumn{10}{c}{ Tablo 12. Ö sermaye çokluğu alt kriteri için müşterilerin karş1laştırma matrisi } \\
\hline $\mathbf{1}$ & $\mathbf{1}$ & $\mathbf{2}$ & $\mathbf{3}$ & $\mathbf{4}$ & $\mathbf{5}$ & $\mathbf{6}$ & $\mathbf{7}$ & $\mathbf{8}$ & $\mathbf{9}$ & $\mathbf{1 0}$ \\
$\mathbf{2}$ & 1 & 0,42 & 1,1 & 0,57 & 0,25 & 0,57 & 1,28 & 0,14 & 0,7 & 0,85 \\
$\mathbf{3}$ & 2,33 & 1 & 2,66 & 1,33 & 0,66 & 1,33 & 3 & 0,33 & 0,6 & 2 \\
$\mathbf{4}$ & 1,75 & 0,75 & 2 & 1 & 0,5 & 1 & 2,25 & 0,25 & 1,25 & 1,4 \\
$\mathbf{5}$ & 4 & 1,5 & 5 & 2 & 1 & 2 & 4,5 & 0,5 & 2 & 3 \\
$\mathbf{6}$ & 1,75 & 0,75 & 2 & 1 & 0,5 & 1 & 2,25 & 0,25 & 1,25 & 1,5 \\
$\mathbf{7}$ & 0,77 & 3 & 0,9 & 0,44 & 0,22 & 0,44 & 1 & 0,11 & 0,55 & 0,55 \\
$\mathbf{8}$ & 7 & 3 & 8 & 4 & 2 & 4 & 9 & 1 & 5 & 6 \\
$\mathbf{9}$ & 1,42 & 1,66 & 2 & 0,8 & 0,5 & 0,8 & 1,8 & 0,2 & 1 & 1,2 \\
$\mathbf{1 0}$ & 1,17 & 0,5 & 1,42 & 0,71 & 0,33 & 0,66 & 1,8 & 0,16 & 0,83 & 1 \\
\hline
\end{tabular}

*Belirlenen Ağırlıklar: W1=0.09, W2=0.09, W3=0.10, W4=0.08, W5=0.14, W6=0.08, W7=0.12, W8=0.10, $\mathrm{W} 9=0.11$, W10 $=0.09$

\section{İdeal Çözüm}

\begin{tabular}{|c|c|c|c|c|c|c|c|c|c|c|}
\hline $\operatorname{MIN}\left(\mathrm{A}^{-}\right)$ & 0,01 & 0,01 & 0,01 & 0,01 & 0,01 & 0,01 & 0,01 & 0,01 & 0,01 & 0,01 \\
\hline $\operatorname{MAK}\left(\mathrm{A}^{*}\right)$ & 0,07 & 0,05 & 0,08 & 0,06 & 0,11 & 0,06 & 0,09 & 0,08 & 0,09 & 0,07 \\
\hline $\mathrm{S}_{\mathrm{I}}^{*}$ & 0,160871 & 0,109351 & 0,172308 & 0,147144 & 0,257505 & 0,147622 & 0,219437 & 0,184807 & 0,225819 & 0,167821 \\
\hline $\mathrm{S}_{\mathrm{I}}^{-}$ & 0,073054 & 0,07383 & 0,08103 & 0,064607 & 0,115428 & 0,064646 & 0,096625 & 0,080814 & 0,090877 & 0,081669 \\
\hline $\mathrm{C}_{\mathrm{I}}^{*}$ & 0,312296 & 0,403046 & 0,319849 & 0,305108 & 0,309514 & 0,30455 & 0,305716 & 0,304245 & 0,286954 & 0,327343 \\
\hline
\end{tabular}

İdeal çözüm değerlerine göre, öz sermaye çokluğu kriterine göre 2. müşteri en önemli müşteri grubu olarak belirlenmiştir.

h. Yatırım Rakamlarına Katkısı Alt Kriterine Göre Müşterilerin Değerlendirilmesi

\begin{tabular}{cccccccccccc}
\multicolumn{10}{c}{ Tablo 13. Yatırım rakamlarına katk1si alt kriteri için müşterilerin karşılaştırma matrisi } \\
\hline $\mathbf{1}$ & $\mathbf{1}$ & $\mathbf{2}$ & $\mathbf{3}$ & $\mathbf{4}$ & $\mathbf{5}$ & $\mathbf{6}$ & $\mathbf{7}$ & $\mathbf{8}$ & $\mathbf{9}$ & $\mathbf{1 0}$ \\
$\mathbf{2}$ & 1 & 0,22 & 0,3 & 0,22 & 0,6 & 0,88 & 0,45 & 0,5 & 0,68 & 0,11 \\
$\mathbf{3}$ & 3,54 & 1 & 1,5 & 1 & 3 & 4 & 2 & 2,4 & 3,5 & 0,5 \\
$\mathbf{4}$ & 4,33 & 0,66 & 1 & 0,66 & 2 & 2 & 1,25 & 1,6 & 2,33 & 0,33 \\
$\mathbf{5}$ & 1,66 & 0,33 & 0,5 & 0,33 & 1 & 1,2 & 0,65 & 0,83 & 1,16 & 0,16 \\
$\mathbf{6}$ & 1,13 & 0,25 & 0,5 & 0,25 & 0,83 & 1 & 0,5 & 0,63 & 0,9 & 0,13 \\
$\mathbf{7}$ & 2,22 & 0,5 & 0,8 & 0,5 & 1,53 & 2 & 1 & 1,25 & 1,75 & 0,25 \\
$\mathbf{8}$ & 2 & 0,41 & 0,63 & 0,4 & 1,2 & 1,58 & 0,8 & 1 & 1,4 & 0,2 \\
$\mathbf{9}$ & 1,47 & 0,28 & 0,43 & 0.33 & 0,86 & 1,1 & 0,57 & 0,71 & 1 & 0,14 \\
$\mathbf{1 0}$ & 9 & 2 & 3 & 2 & 6 & 8 & 4 & 5 & 7 & 1 \\
\hline
\end{tabular}

*Belirlenen Ağırlıklar: W1=0.10, W2=0.09, W3=0.10, W4=0.08, W5=0.13, W6=0.10, $\quad \mathrm{W} 7=0.12, \mathrm{~W} 8=0.10$, W9=0.11, W10 $=0.07$. 


\section{İdeal Çözüm}

\begin{tabular}{|ccccccccccc|}
\hline MiN(A-) & 0,01 & 0,01 & 0,01 & 0,01 & 0,01 & 0,01 & 0,01 & 0,01 & 0,01 & 0,01 \\
MAK(A*) & 0,07 & 0,07 & 0,07 & 0,06 & 0,10 & 0,08 & 0,09 & 0,08 & 0,08 & 0,05 \\
$\mathrm{Si}_{\mathrm{I}}^{*}$ & 0,164305 & 0,152566 & 0,166743 & 0,134948 & 0,219648 & 0,174759 & 0,204694 & 0,171791 & 0,191757 & 0,118829 \\
$\mathrm{~S}_{\mathrm{I}}^{-}$ & 0,080839 & 0,073036 & 0,08255 & 0,064853 & 0,107491 & 0,081307 & 0,096925 & 0,08267 & 0,091266 & 0,07193 \\
$\mathrm{C}_{\mathrm{I}}^{*}$ & 0,329761 & 0,323739 & 0,331138 & 0,324586 & 0,328579 & 0,317522 & 0,321348 & 0,324883 & 0,322468 & 0,377073 \\
\hline
\end{tabular}

Elde edilen ideal çözüm değerlerine göre, 10. müşteri, yatırım kararlarına katkısı kriterine göre en yüksek öneme sahip müşteri grubudur.

\section{i. Yüksek Tutarlı Mevduat Kullanımı Alt Kriterine Göre Müşterilerin Değerlendirilmesi}

\begin{tabular}{ccccccccccc}
\multicolumn{10}{c}{ Tablo 14. Yüksek tutarlı mevduat kullanımı alt kriteri için müşterilerin karşlaşstırma matrisi } \\
\hline & $\mathbf{1}$ & $\mathbf{2}$ & $\mathbf{3}$ & $\mathbf{4}$ & $\mathbf{5}$ & $\mathbf{6}$ & $\mathbf{7}$ & $\mathbf{8}$ & $\mathbf{9}$ & $\mathbf{1 0}$ \\
$\mathbf{1}$ & 1 & 0,66 & 0,5 & 0,5 & 0,16 & 1,5 & 0,8 & 1,3 & 0,3 & 1 \\
$\mathbf{2}$ & 1,5 & 1 & 0,7 & 1 & 0,25 & 2 & 1,25 & 2 & 0,5 & 1,6 \\
$\mathbf{3}$ & 2 & 1,42 & 1 & 1 & 0,33 & 3 & 1,5 & 2,5 & 0,65 & 2,1 \\
$\mathbf{4}$ & 2 & 1 & 1 & 1 & 0,33 & 3 & 1,5 & 2 & 0,66 & 2,5 \\
$\mathbf{5}$ & 6 & 4 & 3 & 3 & 1 & 9 & 5 & 8 & 2 & 7 \\
$\mathbf{6}$ & 0,66 & 0,5 & 0,33 & 0,33 & 0,11 & 1 & 0,5 & 0,88 & 0,22 & 0,7 \\
$\mathbf{7}$ & 1,25 & 0,8 & 0,66 & 0,66 & 0,2 & 2 & 1 & 1,6 & 0,4 & 1,3 \\
$\mathbf{8}$ & 0,76 & 0,5 & 0,4 & 0,5 & 0,13 & 1,13 & 0,63 & 1 & 0,2 & 0,85 \\
$\mathbf{9}$ & 3,33 & 2 & 1,53 & 1,5 & 0,5 & 4,54 & 2,5 & 5 & 1 & 3,5 \\
$\mathbf{1 0}$ & 1 & 0,63 & 0,47 & 0,4 & 0,14 & 1,42 & 0,77 & 1,17 & 0,29 & 1 \\
\hline
\end{tabular}

*Belirlenen Ağırlıklar: $\mathrm{W}_{1}=0.13, \mathrm{~W}_{2}=0.10, \mathrm{~W}_{3}=0.11, \mathrm{~W}_{4}=0.08, \mathrm{~W}_{5}=0.12, \mathrm{~W}_{6}=0.10, \mathrm{~W}_{7}=0.06, \mathrm{~W}_{8}=0.09, \mathrm{~W}_{9}=0.10$, $\mathrm{W}_{10}=0.11$.

\section{İdeal Çözüm}

\begin{tabular}{|cccccccccccc}
\hline MiN(A $\left(\mathrm{A}^{*}\right)$ & 0,01 & 0,01 & 0,01 & 0,01 & 0,01 & 0,01 & 0,00 & 0,01 & 0,01 & 0,01 \\
MAK(A*) & 0,10 & 0,08 & 0,09 & 0,06 & 0,09 & 0,08 & 0,05 & 0,07 & 0,08 & 0,09 \\
$\mathrm{~S}_{\mathrm{I}}^{*}$ & 0,226479 & 0,181813 & 0,195636 & 0,138191 & 0,216331 & 0,178935 & 0,110245 & 0,158565 & 0,182078 & 0,202004 \\
$\mathrm{~S}_{\mathrm{I}}^{-}$ & 0,105181 & 0,078411 & 0,088738 & 0,064404 & 0,096909 & 0,080518 & 0,049397 & 0,073402 & 0,082479 & 0,086496 \\
$\mathrm{C}_{\mathrm{I}}^{*}$ & 0,317136 & 0,301322 & 0,312048 & 0,317894 & 0,309376 & 0,310338 & 0,309425 & 0,316431 & 0,311762 & 0,299813 \\
\hline
\end{tabular}

İdeal çözüm değerlerine göre 4. müşteri, yüksek tutarlı mevduat kullanımı kriterine göre en önemli müşteri grubu olarak belirlenmiştir.

\section{j. $\quad$ Çapraz Ürün Satışı Alt Kriterine Göre Müş̧terilerin Değerlendirilmesi}

Tablo 15. Çapraz ürün satışı alt kriteri için müşterilerin karşılaştırma matrisi

\begin{tabular}{cccccccccccc}
\multicolumn{10}{c}{ Tablo 15. Çapraz ürün satış1 alt kriteri için müşterilerin karşılaştırma matrisi } \\
\hline $\mathbf{1}$ & $\mathbf{1}$ & $\mathbf{2}$ & $\mathbf{3}$ & $\mathbf{4}$ & $\mathbf{5}$ & $\mathbf{6}$ & $\mathbf{7}$ & $\mathbf{8}$ & $\mathbf{9}$ & $\mathbf{1 0}$ \\
$\mathbf{2}$ & 1 & 0,75 & 1,5 & 1,5 & 0,75 & 2 & 0,5 & 2 & 0,25 & 1,2 \\
$\mathbf{3}$ & 1,33 & 1 & 2,1 & 2 & 1 & 3 & 0,5 & 2,5 & 0,33 & 1,66 \\
$\mathbf{4}$ & 0,66 & 0,47 & 1 & 1 & 1,5 & 1,28 & 0.28 & 1,1 & 0,14 & 0,71 \\
$\mathbf{5}$ & 1,33 & 1 & 0,66 & 2 & 1 & 3 & 0,5 & 2,5 & 0,33 & 1,66 \\
$\mathbf{6}$ & 0,5 & 0,33 & 0,78 & 0,66 & 0,33 & 1 & 0,22 & 0,88 & 0,11 & 0,55 \\
$\mathbf{7}$ & 2 & 2 & 3,57 & 3,33 & 2 & 4,54 & 1 & 3,4 & 0,5 & 2 \\
$\mathbf{8}$ & 0,5 & 0,4 & 0,9 & 0,75 & 0,4 & 1,13 & 0,29 & 1 & 0,13 & 0,6 \\
$\mathbf{9}$ & 4 & 3 & 7 & 6 & 3 & 9 & 2 & 8 & 1 & 5 \\
\hline
\end{tabular}




\begin{tabular}{lllllllllll}
\hline $\mathbf{1 0}$ & 0,83 & 0,61 & 1,4 & 1,25 & 0,6 & 1,81 & 0,5 & 1,66 & 0,2 & 1
\end{tabular}

*Belirlenen Ağırlıklar: $\mathrm{W}_{1}=0.11, \mathrm{~W}_{2}=0.10, \mathrm{~W}_{3}=0.11, \mathrm{~W}_{4}=0.08, \mathrm{~W}_{5}=0.12, \mathrm{~W}_{6}=0.10, \mathrm{~W}_{7}=0.08, \mathrm{~W}_{8}=0.11, \mathrm{~W}_{9}=0.10$, $\mathrm{W}_{10}=0.09$.

\section{İdeal Çözüm}

\begin{tabular}{|c|c|c|c|c|c|c|c|c|c|c|}
\hline $\operatorname{MIN}\left(\mathrm{A}^{-}\right)$ & 0,01 & 0,01 & 0,01 & 0,01 & 0,01 & 0,01 & 0,01 & 0,01 & 0,01 & 0,01 \\
\hline $\operatorname{MAK}\left(\mathrm{A}^{*}\right)$ & 0,09 & 0,07 & 0,09 & 0,06 & 0,08 & 0,08 & 0,06 & 0,09 & 0,08 & 0,07 \\
\hline $\mathrm{S}_{\mathrm{I}}^{*}$ & 0,19562 & 0,166661 & 0,215736 & 0,139427 & 0,180333 & 0,180684 & 0,149285 & 0,206133 & 0,180275 & 0,169183 \\
\hline $\mathrm{S}_{\mathrm{I}}^{-}$ & 0,08608 & 0,081677 & 0,092334 & 0,064733 & 0,098006 & 0,080645 & 0,064575 & 0,08848 & 0,080757 & 0,0763 \\
\hline $\mathrm{C}_{\mathrm{I}}^{*}$ & 0,305573 & 0,328896 & 0,299717 & 0,31707 & 0,35211 & 0,308597 & 0,301948 & 0,300327 & 0,309376 & 0,310816 \\
\hline
\end{tabular}

Elde edilen ideal çözüm değerlerine göre, çapraz ürün satışı kriterine göre, en önemli müşteri grubu 2. müşteridir.

\section{k. Yüksek Tutarlı Kredi Alt Kriterine Göre Müşterilerin Değerlendirilmesi}

\begin{tabular}{ccccccccccc}
\multicolumn{10}{c}{ Tablo 16. Yüksek tutarlı kredi alt kriteri için müşterilerin karşılaştırma matrisi } \\
\hline & $\mathbf{1}$ & $\mathbf{2}$ & $\mathbf{3}$ & $\mathbf{4}$ & $\mathbf{5}$ & $\mathbf{6}$ & $\mathbf{7}$ & $\mathbf{8}$ & $\mathbf{9}$ & $\mathbf{1 0}$ \\
$\mathbf{1}$ & 1 & 1,2 & 1 & 1,1 & 1 & 0,75 & 1,8 & 1,6 & 0,9 & 0,2 \\
$\mathbf{2}$ & 0,83 & 1 & 1 & 1,16 & 1 & 0,6 & 1,5 & 1,33 & 0,5 & 0,16 \\
$\mathbf{3}$ & 1 & 1 & 1 & 1,16 & 1 & 0,6 & 1,5 & 1,33 & 0,5 & 0,16 \\
$\mathbf{4}$ & 0,9 & 0,86 & 0,86 & 1 & 0,85 & 0,5 & 1,5 & 1,2 & 0,4 & 0,14 \\
$\mathbf{5}$ & 1 & 1 & 1 & 1,17 & 1 & 0,6 & 1,5 & 1,33 & 0,5 & 0,16 \\
$\mathbf{6}$ & 1,33 & 1,66 & 1,66 & 2 & 1,66 & 1 & 2,25 & 2 & 0,75 & 0,25 \\
$\mathbf{7}$ & 0,55 & 0,66 & 0,66 & 0,66 & 0,66 & 0,44 & 1 & 0,88 & 0,33 & 0,11 \\
$\mathbf{8}$ & 0,63 & 0,75 & 0,75 & 0,83 & 0,75 & 0,5 & 1,13 & 1 & 0,3 & 0,13 \\
$\mathbf{9}$ & 1,1 & 2 & 2 & 2,5 & 2 & 1,33 & 3 & 3,33 & 1 & 0,33 \\
$\mathbf{1 0}$ & 5 & 6 & 6 & 7 & 6 & 4 & 9 & 8 & 3 & 1 \\
\hline
\end{tabular}

*Belirlenen Ağırlıklar: $\mathrm{W}_{1}=0.09, \mathrm{~W}_{2}=0.13, \mathrm{~W}_{3}=0.11, \mathrm{~W}_{4}=0.08, \mathrm{~W}_{5}=0.14, \mathrm{~W}_{6}=0.09, \mathrm{~W}_{7}=0.08, \mathrm{~W}_{8}=0.11, \mathrm{~W}_{9}=0.07$, $\mathrm{W}_{10}=0.10$.

\section{İdeal Çözüm}

\begin{tabular}{|cccccccccccc|}
\hline MiN(A $)$ & 0,01 & 0,01 & 0,01 & 0,01 & 0,01 & 0,01 & 0,01 & 0,01 & 0,01 & 0,01 \\
MAK(A $\left.{ }^{*}\right)$ & 0,08 & 0,11 & 0,09 & 0,07 & 0,12 & 0,08 & 0,07 & 0,09 & 0,06 & 0,09 \\
S $_{\mathrm{I}}^{*}$ & 0,191225 & 0,272733 & 0,232871 & 0,168748 & 0,296503 & 0,194476 & 0,16819 & 0,225271 & 0,144791 & 0,212857 \\
$\mathrm{~S}_{\mathrm{I}}^{-}$ & 0,072498 & 0,105124 & 0,089107 & 0,066806 & 0,113422 & 0,073195 & 0,064495 & 0,089125 & 0,057676 & 0,06811 \\
$\mathrm{C}_{\mathrm{I}}^{*}$ & 0,274902 & 0,278211 & 0,27675 & 0,283613 & 0,27669 & 0,273452 & 0,277177 & 0,283481 & 0,284866 & 0,242413 \\
\hline
\end{tabular}

Elde edilen ideal çözüm değerlerine göre, yüksek tutarlı kredi kriterine göre, 9. müşteri en önemli müşteri grubu olarak belirlenmiştir.

\section{Tartışma ve Sonuç}

Finans kurumunun ihtiyaç duyduğu duruma göre hangi müş̧teri beklentilerini karşllayacak şekilde strateji belirlemesi gerektiği elde edilen sonuçlar içinden belirlenecektir. Karar verme süreciyle elde edilen sonuçlar şu şekildedir: Müşteri getirmesinin önemli olduğu durumlarda 7. ve 9. Müşterilerine öncelik vermeli, güvenilirlik kriteri ve yüksek tutarlı mevduat kriteri ön plana çıkarsa 9. Müşteriye 
öncelik vermelidir. Fazla şubesi olması kriterine ve yatırım rakamlarına katkısı kriterlerine göre 10. Müşteri’ye öncelik vermelidir. 2. Müşteri öz sermaye çokluğu ve çapraz ürün satışı kriterlerine göre en önemli müsşeri grubu olarak tercih edilecektir. Son olarak yüksek tutarlı kredi kullanımı kriterine göre ise 4. Müşteri tercih edilecektir.

Genel olarak bakacak olursak Ciroya katkısının önemli olduğu durumlarda, 2, 4 ve 9. Müşterileri dikkate almaları gerekmektedir. Bunların içerisinde ise en yüksek önceliğe sahip olan Yüksek Tutarlı Kredi Kullanımı kriterine göre ise 9. Müşteri en önemli müşteri olarak belirlenebilir. Tüm alt kriterlere göre değerlendirmede de 3 farklı kritere göre yine 9 . Müşteri en önemli müşteri olarak tanımlanmıştır.

Çalışmanın sonuçlarına bakacak olursak, başlangıçta 10 müşteri olarak belirlenmiş olan müşteri grupları, karar verme süreci sonunda genel olarak 3 müşteriye indirilmiştir. Hatta bunların içerinde ön önemli müşseri grubunun 9. Müşteri olduğu da belirtilebilir.

\section{Kaynaklar}

[1] Çınar, Y., "Çok Nitelikli Karar Verme ve Bankaların Mali Performanslarının Değerlendirilmesi Örneği”, Ankara Üniversitesi Sosyal Bilimler Enstitüsü, Yüksek Lisans Tezi, İşletme Anabilim Dalı, Ankara, 2004.

[2] Bircan, K., Acayip, E., Okursoy, A., "Bankacilik Sektöründe Müşteri İlişkileri Yönetimi ve Çalışanlar Tarafindan Değerlendirilmesi”, Ekev Akademi Dergisi, Y11: 18 Sayı: 58, ss. 647-662 2014.

[3] Özdemir, İ., "Bankacılıkta Halkla İlişkiler ve Müşteri İlişkileri”, Bankacılık ve Sigortacıllk Araştırmalart Dergisi, Cilt 1 Sayı 3-4, ss.4-15, 2012.

[4] Demirel, Y., "Türk Bankacılık Sektöründe Müşteri İlişkileri Yönetimi'nin Müşteri Sadakati Üzerine Etkisi”, Kocaeli Üniversitesi Sosyal Bilimler Enstitüsü Dergisi (13), 1 : 56-81 2007.

[5] Özen, E., "Bireysel Bankacılıkta Güven, Önem ve Maliyet Algılarının Sadakat Algısına Etkisi", Finans Politik \& Ekonomik Yorumlar, Cilt: 51 Say1: 594, 2014.

[6] Demireli, E., "TOPSIS Çok Kriterli Karar Verme Sistemi: Türkiye'deki Kamu Bankaları Üzerine Bir Uygulama”, Girişimcilik ve Kalkınma Dergisi, 5(1), ss. 101-112, 2010.

[7] Cheng-Ru W., Chın-Tsa1 L., Pe1-Hsuan T., "Financial Service of Wealth Management Banking: Balanced Scorecard Approach”, Journal of Social Sciences 4 (4), pp.255-263, 2008.

[8] Tasai H. Y., Bao-Huey, Wang Huang, Siou A., "Combining ANP And TOPSIS Concepts For Evaluation The Performance Of Property-Liability Insurance Companies”, Journal Of Social Sciences 4 (1), pp.56-61, 2008.

[9] Manabendra, N. P., Choudhury K., "Exploring The Dimensionality Of Service Quality: An Application Of TOPSIS In The Indian Banking Industry”, Asia-Pacific Journal of Operational Research Vol. 26, No. 1, pp. 115-133, 2009.

[10] Tolga, A.Ç., "Fuzzy Multicriteria R\&D Project Selection With A Real Options Valuation Model”, Journal Of Intelligent \& Fuzzy Systems 19, pp.359-371, 2008.

[11] Seçme, Y. N. Bayrakdaroğlu A., Kahraman C, "Fuzzy Performance Evaluation In Turkish Banking Sector Using Analytic Hierarchy Process And TOPSIS", Expert Systems With Applications 36, pp. 11699-11709, 2009. 
[12] İç, Y.T. ve Yurdakul M., "Developments Of A Quick Credibilty Scoring Decision Support System Using Fuzzy TOPSIS”, Expert Systems With Apllications 37, pp.567-574, 2010.

[13] Saldanlı, A., Sırma İ., “Topsis Yönteminin Finansal Performans Göstergesi Olarak Kullanılabilirliği”, Marmara Üniversitesi, Öneri Dergisi, Cilt 11, Sayı 41. 2014.

[14] Güneysu, Y., Er B., Murat İ., “Art Türkiye'deki Ticari Bankalarin Performanslarının Ahs Ve Gia Yöntemleri İle İncelenmesi”, KTU SBE Sosyal Bilimler Dergisi, (9), ss. 71-93, 2015.

[15] Soba M., "Banka Yeri Seçiminin Analitik Hiyerarşi Süreci Ve Electre Metodu İle Belirlenmesi: Uşak İlçeleri Örneği”, Mustafa Kemal Üniversitesi Sosyal Bilimler Enstitüsü Dergisi (11), Say1: 25, ss. 459-473, 2014.

[16] Dinçer, H., Görener, A., “ Performans Değerlendirmesinde Ahp - Vikor Ve Ahp - Topsis Yaklaşimlari: Hizmet Sektöründe Bir Uygulama”, Sigma Mühendislik ve Fen Bilimleri Dergisi, 39, 244-260, 2011.

[17] Bağcı H., Rençber Ö.F, "Kamu Bankaları ve Halka Açık Özel Bankaların Promethee Yöntemi İle Kârlılıklarının Analizi”, Aksaray Üniversitesi İktisadi ve İdari Bilimler Fakültesi Dergisi, 6(1) ss. 39-47, 2014.

[18] Aktan, C. C, “2000’li Y1llarda Yeni Yönetim Teknikleri (2) Stratejik Yönetim”, İstanbul: TÜGIAD Yayını, 1999.

[19] Torlak, Ö., Altunışık R., Özdemır Ş., "Modern Pazarlama", İstanbul: Değişim Yayınları, 2002.

[20] Dumanoğlu, S., Ergül N., “İMKB'de İşlem Gören Teknoloji Şirketlerinin Mali Performans Ölçümü”, Muhasebe ve Finansman Dergisi, 48, 101-111, 2010.

[21] Mahmoodzadeh S., Shahrabı J., Parıazar M., Zaerı M. S., "Project Selection by Using Fuzzy AHP and TOPSIS Technique”, World Academy of Science, Engineering and Technology, 30, pp. 333-338, 2007. 